\begin{tabular}{|l|l|l||}
\hline \multicolumn{2}{|c|}{ PublisherInfo } \\
\hline \hline PublisherName & $:$ & BioMed Central \\
\hline \hline PublisherLocation & $:$ & London \\
\hline \hline PublisherImprintName & $:$ & BioMed Central \\
\hline \hline
\end{tabular}

\title{
Keeping an eye on glaucoma
}

\begin{tabular}{|l|l|l||}
\hline \multicolumn{2}{|c|}{ ArticleInfo } \\
\hline \hline ArticleID & $:$ & 4717 \\
\hline \hline ArticleDOI & $:$ & $10.1186 /$ gb-spotlight-20030307-02 \\
\hline \hline ArticleCitationID & $:$ & spotlight-20030307-02 \\
\hline \hline ArticleSequenceNumber & $:$ & 69 \\
\hline \hline ArticleCategory & $:$ & Research news \\
\hline ArticleFirstPage & $:$ & 1 \\
\hline \hline ArticleLastPage & $:$ & 2 \\
\hline \hline & & RegistrationDate : 2003-3-7 \\
\hline ArticleHistory & $:$ & OnlineDate \\
\hline \hline ArticleCopyright & $:$ & BioMed Central Ltd2003-7 \\
\hline \hline ArticleGrants & $:$ & \\
\hline \hline ArticleContext & $:$ & 130594411 \\
\hline \hline
\end{tabular}




\section{Jonathan B Weitzman}

Email: jonathanweitzman@hotmail.com

Glaucoma is the leading cause of irreversible blindness and affects millions worldwide. Patients with primary congenital glaucoma (PCG) often have mutations in the cytochrome P450 family 1, subfamily $\mathrm{B}$, polypeptide 1 (CYPIB1) gene. In the March 7 Science, Libby et al. report the characterization of a Cyplb1 $1^{-/-}$knockout mouse as a model for PCG (Science 2003, 299:1578-1581). The mice had developmental eye defects similar to those seen in human patients. Genetic and histological analysis revealed a role for the tyrosinase gene as a genetic modifier. Tyrosinase also modifies the anterior segment dysgenesis phenotypes observed in mice lacking the Foxcl gene that has also been implicated in PCG. Tyrosinase converts tyrosine to L-dopa, and the ocular phenotypes of the knockout mice could be relieved by the administration of L-dopa. This study suggests that L-dopa should be tested as a possible therapeutic for treating glaucoma patients.

\section{References}

1. Anterior segment dysgenesis and the developmental glaucomas are complex traits.

2. Phenotype of cytochrome P4501B1 gene (CYP1B1) mutations in Japanese patients with primary congenital glaucoma.

3. Science, [http://www.sciencemag.org] 